\title{
PHYSIOLOGICAL AND BIOCHEMICAL RESPONSES OF THREE ECOTYPES OF CAROB (CERATONIA SILIQUA L.) AGAINST DROUGHT STRESS IN ALGERIA
}

\author{
GADOUM, A. ${ }^{{ }^{*}}-$ AdDA, A. ${ }^{2}-$ SAHNOUNE, M. ${ }^{2}-$ AID, F. $^{1}$ \\ ${ }^{1}$ Laboratory of Biology and Physiology of Organisms, University of Sciences and Technology \\ Houari Boumediene, BP 32 El-Alia, Bab Ezzouar, 16111 Alger, Algérie \\ (phone/fax: +213-21-247-217) \\ ${ }^{2}$ Laboratory of Plant Biotechnology and Genetic Improvement of Plants, University Ibn \\ Khaldoun, $B P$ 78, 14000 Tiaret, Algérie \\ (phone: +213-40-777-167; fax: +213-42-415-886) \\ *Corresponding author \\ e-mail: abdelkadergadoum@yahoo.fr; phone: +213-670-177-112; fax:+213-21-247-217 \\ (Received $9^{\text {th }}$ Sep 2018; accepted $2^{\text {nd }}$ Jan 2019)
}

\begin{abstract}
The greatest failure rate of reforestation programs in Algeria is related to the water deficit especially at young plant stage. Hence, the objective of this paper is to study the responses to drought stress generated by three different water regimes 100\% (control), 60\% (moderate stress) and 40\% (severe stress) of field capacity (FC) on 3 young populations of Ceratonia siliqua L. in Algeria with different eco-geographical origins (Zeralda, Tissemsilt and Ain Sefra). The germination seeds of these populations were conducted in February 2013. The results exhibit a significant decrease in stomata conductance (cs) and in relative water content (RWC) with the increase in the intensity of drought stress. Negative and significant correlations were recorded between the RWC and the intensity of drought stress in the studied plants compared to the control plants. A considerable increase of proline and soluble sugar was positively correlated with drought stress severity for the three ecotypes of Ceratonia siliqua L. Significant differences in the chlorophyll and carotenoid content were detected among the three ecotypes in three water regimes. According to the canonical discriminant analysis of our data, the three ecotypes were separated by the physiological and biochemical parameters studied. It is clear that the ability of drought tolerance in the three studied contrasting ecotypes is different. We suggest the following order with respect to the ability of drought tolerance: Ain Sefra - Tissmesilt - Zeralda.
\end{abstract}

Keywords: water regimes, proline, soluble sugar, young plant, relative water content

\section{Introduction}

Most of Mediterranean natural plants are exposed to persistent and severe drought stress (Nogués and Baker, 2000). Drought, the most important abiotic stress, affects the physiological and biochemical process in plants leading to a reduction of growth and productivity (Yoon et al., 2014; Lambers et al., 2008).

Drought significantly reduces germination mainly due to low water absorption during the imbibition phase of germination, to the low energy supply and to the decreased enzyme activity (Okcu et al., 2005; Taiz and Zeiger, 2010). It also reduces leaf size, stem elongation and root proliferation, and disturbed stomata variations, plant water and nutrient relations with diminished crop productivity (Li et al., 2009).

Responses of plants to drought stress in the arid and semi-arid areas are complex and different mechanisms (morpho-anatomical, physiological, biochemical and molecular) involve allowing the plant to survive (Rodziewicz et al., 2014). There are often the main mechanisms of tolerance to water deficit (Tardieu, 2005); (i) maintenance of leaf water 
potential (RWC, stomatal conductance), (ii) the biosynthesis and accumulation of various osmolytes (proline, soluble sugars), (iii) and the activation of different resistant genes (Chaves et al., 2003; Reddy et al., 2004).

In Algeria, a gradual rise in aridity towards the north was observed over the past thirty years. This aridity is marked by a pronounced increase in the degradation of all components of the ecosystem (Ait Chitt et al., 2007).

This desertification, which reaches the most advanced stage of land degradation resulted in the reduction of biological potential, the breakdown of ecological and socioeconomic equilibrium, and a remarkable regression of plant genetic resources (Le Houérou, 1985). Central and north-western regions of Algeria are characterized by rare and irregular rainfall, and long dry summer periods (Batlle and Tous, 1997). Forests are in a perpetual decline due to anthropogenic activities such as forest fires, overgrazing, and uncontrolled urbanization (Batlle and Tous, 1997). As a result, several forest development programs have been implemented in many areas of Algeria. To that end, the government uses the multipurpose tree and drought resistant species that exhibit morpho- physiological traits and genetic adaptation to climatic variation (Ait Chitt et al., 2007). Among these species is Ceratonia siliqua L. which is a perennial evergreen tree. It is an agro-sylvo-pastoral species with enormous socio-economic and ecological interests (Batlle and Tous, 1997; Gharnit et al., 2001). Carob tree is considered one of the most interesting forest trees since all its parts (leaves, flowers, fruits, wood, bark, and roots) are exploited (Aafi, 1996).

Although carob tree is a non-nodulable species, endophytic associative bacteria can be observed in their root systems (Nautiyal et al., 2000; Reva et al., 2002).

The presence of these bacteria inside vegetative tissues would probably contribute significantly to the palliation of nutritional deficiencies of carob, which settles favorably on poor soils. They have a great ability to solubilize and release certain mineral or organic elements such as phosphorus and iron origins essential for plant nutrition (Konate, 2007).

The carob tree is mainly concentrated in coastal, semi-arid and arid zones, owing to its great ability to develop adaptation strategies by reducing its leaf area, leaf curling (Rejeb, 1995; Batlle and Tous, 1997) and enhancing the growth of its root system. Often, the response of a plant with a water deficit results in a preferential allocation of biomass to the roots expressed by an increase in the dry matter ratio between the underground part and the aerial part (Gales, 1979; Benbelkacem et al., 2000; Albouchi et al., 2003).

The greatest failure rate of revegetation programs faced by carob trees is at the seedling stage. The installation of the seedling root system requires adequate soil hydration and will be more difficult in heavy areas characterized by a high saturation deficit (Letreuch, 1991). Vegetation with weak rooting can disappear; also, we propose the study of physiological mechanisms of resistance to drought stress on three ecotypes of Ceratonia siliqua L. aged 18 months, from three different bioclimatic regions of Algeria.

\section{Materials and methods}

\section{Plant material}

Populations of Ceratonia siliqua L. were collected from three different bioclimatic stages in the Centre and North-Western of Algeria respectively in Zeralda (wet 
bioclimatic stage), Tissemsilt (upper semi-arid bioclimatic stage) and Ain Sefra (arid bioclimatic stage). Climatic, geographical and hydrological conditions of these three regions are markedly different (Table 1). Sapling locations are illustrated in (Fig. 1).

Table 1. Geographical and climatic characteristics of the different sites of Ceratonia siliqua L. ecotypes. (ANAT, 2004)

\begin{tabular}{c|c|c|c|c|c|c}
\hline Ecotype & Latitude & Longitude & Altitude $(\mathbf{m})$ & Pluviométrie & $\mathbf{T}$ min $\left({ }^{\circ} \mathbf{C}\right)$ & $\mathbf{T}$ max $\left({ }^{\circ} \mathbf{C}\right)$ \\
\hline Zeralda & $36.7040 \mathrm{~N}$ & $2.8672 \mathrm{~W}$ & 30 & $600-900$ & $0-9$ & $28-31$ \\
Tissemsilt & $35.9049 \mathrm{~N}$ & $1.5248 \mathrm{~W}$ & 866 & $400-600$ & $2-4$ & $33-38$ \\
Ain Sefra & $32.7439 \mathrm{~N}$ & $-0.8801 \mathrm{~W}$ & 1078 & $100-300$ & -10 & $35-42$ \\
\hline
\end{tabular}

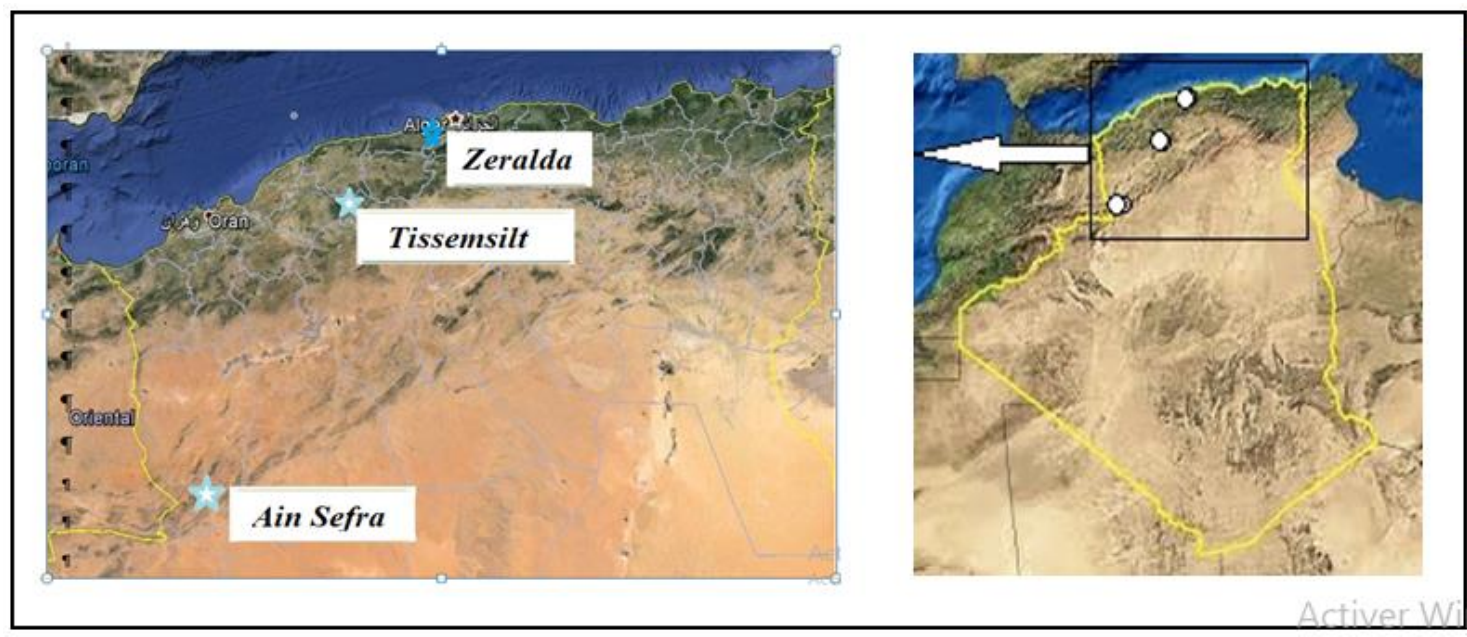

Figure 1. Repartition map of the different sites of Ceratonia siliqua L. ecotypes of Algerian carob populations

\section{Culture conditions}

After being scarred with a sharp instrument at the opposite side of the embryo, seeds were disinfected using bleach diluted for $10 \mathrm{~min}$ and finally rinsed twice with distilled water and deposited in Petri dishes on filter paper a reason of 10 seeds per petri dish. Petri dishes were put in an oven $48 \mathrm{~h}$ at $27{ }^{\circ} \mathrm{C}$ in the dark. Germination rate are $54.5 \%$, 100\%and 74.4\% for Zeralda, Tissemsilt and Ain Sefra, respectively.

Plants were transferred into pots $(15 \times 27 \mathrm{~cm})$ filled with a mixture of peat and soil $2 / 3(\mathrm{v} / \mathrm{v})$ with one seedling per pot and watered daily with tap water. The experiment was conducted at $28 \pm 1{ }^{\circ} \mathrm{C}$ and the range of relative humidity is $60 \%$ to $70 \%$ over 18 months.

The experiments were performed during July 2015, on plants at the same stage of development. 162 young plants of Ceratonia siliqua L., 18 months old have been divided into three groups which undergo three different water regimes:100\% (control), $60 \%$ (moderate stress) and $40 \%$ (severe stress) of field capacity (FC).

The treatments were applied during two months and each treatment included eighteen plants for each ecotype. Leaves were collected after seventeen days of treatment. Three plants per treatment were used for each experiment. 


\section{Physiological parameters}

\section{Relative water content}

The water status of the plants is measured by the Relative Water Content (RWC) according to Ladiges (1975), used by Clarke et al. (1982) and Rascio et al. (1988). RWC calculations were made according to Equation 1:

$$
\operatorname{RWC}(\%)=[(\mathrm{FW}-\mathrm{DW}) /(\mathrm{TW}-\mathrm{DW})] \times 100
$$

where FW, TW and DW refer to fresh weight, Turgid weight (after $24 \mathrm{~h}$ rehydration on distilled water), and dry weight after oven drying for $48 \mathrm{~h}$ at $70{ }^{\circ} \mathrm{C}$ respectively.

\section{Stomata conductance}

Stomata conductance (CS) was measured using a porometer (AP4DELTA-T Devices, Cambridge, UK) and on 18 month old plants. Measurements were made on fully exposed leaves between $10 \mathrm{~h}$ and $12 \mathrm{~h}$ on the lower face of three young leaves per plant. Stomata conductance has been expressed in $\mathrm{mmol} \mathrm{H}_{2} \mathrm{O} / \mathrm{m}^{2} \mathrm{~s}^{-1}$.

\section{Biochemical parameters}

\section{Proline content}

The determination of the proline content is carried out according to the colorimetric method of Troll and Lindsley (1955) later developed by Magné and Larher (1992).

The determination of the proline content is carried out according to the colorimetric method of Troll and Lindsley (1955) later developed by Magné and Larher (1992). Leaf samples $(150 \mathrm{mg}$ ) are extracted by using $3 \mathrm{~mL}$ of methanol placed in batch at 90 ${ }^{\circ} \mathrm{C}$ for $1 \mathrm{~h}$. After cooling, extract $(1 \mathrm{~mL})$ was treated with $2 \mathrm{~mL}$ of ninhydrin solution ( $1 \%$ in glacial acetic acid). After addition of $2 \mathrm{~mL}$ toluene, the mixture is stirred vigorously and the upper phase is removed. The optical density is read at $520 \mathrm{~nm}$ with a spectrophotometer (U.V/visible Shimadzu Modèle V630). The results are referred to a standard curve made of increasing quantities of proline solution. The results are expressed in $\mu \mathrm{g}$. g-1 MS. Three repetitions are planned by treatment between $08 \mathrm{~h}$ and $10 \mathrm{~h}$ (one plant per replicate).

\section{Soluble sugar}

The soluble sugar content (SS) was measured according to Schields and Burnet (1960). $5.25 \mathrm{ml}$ of $80 \%$ ethanol was added to leaf tissues $(100 \mathrm{mg})$ in a test tube at room temperature in the dark. After 20-h extraction, ethanol was evaporated in a water bath at $70{ }^{\circ} \mathrm{C}$. Then, $2 \mathrm{~mL}$ of this solution previously diluted 10 times with ethanol $80 \%$ was transferred into another tube, adding $4 \mathrm{ml}$ of reagent (prepared $4 \mathrm{~h}$ before the test) composed of $2 \mathrm{mg}$ pure anthrone added to $100 \mathrm{~mL}$ of sulfuric acid and vortexing to homogenize the solution. After $10 \mathrm{~min}$, tubes were placed again in the water bath for $08 \mathrm{~min}$ at $92{ }^{\circ} \mathrm{C}$. The absorbance is read at the spectrophotometer (U.V/visible Modèle V630) at a wave length of $585 \mathrm{~nm}$. The results are referred to a standard curve made of increasing quantities of a solution of glucose and the concentration is expressed in $\mu \mathrm{g} \cdot \mathrm{g}^{-1}$ of MS. Three repetitions are planned by treatment (one plant per replicate). 


\section{Chlorophyll pigments}

The levels of chlorophyll $(\mathrm{a}+\mathrm{b})$ and carotenoids are determined according to Lichtenthaler (1987). The extraction is performed through cold acetone. A measure of the absorbance is made of 470, 662 and $645 \mathrm{~nm}$ using a spectrophotometer Shimadzu (UV-1605). The levels in pigments, expressed in $\mu \mathrm{g} \cdot \mathrm{ml}^{-1}$ of MS, are calculated in Equations 2 and 3:

$$
\begin{gathered}
C(a+b)=7.05 \text { A662-18.09 A645 } \\
C(x+c)=(1000 \text { A470 - 1.90Ca }-63.14 C b) 214
\end{gathered}
$$

where $\mathrm{C}(\mathrm{a}+\mathrm{b})$ is total chlorophyll concentration of and $\mathrm{C}(\mathrm{x}+\mathrm{c})$ is caroténoid concentration.

\section{Statistical analysis}

All statistical analyses are performed using SAS 9. On 162 observations, the ANOVA procedure of SAS was used to adjust the generalized linear model (GLM). The fixed factors are the accessions and the different water regimes. The variable factors chosen for this analysis are the various physiological and biochemical parameters.

The signification is chosen for a value of $p=0.05$. In the declaration of the model, the options of Statistics Type 1 and Type 3 are used.

To differentiate between groups of accessions and water regimes which are homogeneous on the statistical plan, we used the test of Waller-Duncan. The meaning $\chi=0.05$ in ANOVA was chosen, with the selection of the ANOVA model means of SAS 9.

All statistical analyses were performed using the Database Software SAS, version 9 for Windows, Version 7. The graphical extrapolation of the results was performed with Microsoft Excel software.

\section{Results}

\section{Physiological parameters}

The relative water content (RWC) of control seedlings of Zeralda ecotype $(87.08 \% \pm 5.16)$ was higher than Tissemsilt and Ain Sefra ecotypes with $83.22 \% \pm 1.23$ and $72.32 \% \pm 7.92$ respectively (Fig. $2 A$ ).

Moderate and severe drought stresses cause a decrease in RWC proportional to the severity of stress. However, Zeralda ecotype still has the largest RWC and Ain Sefra ecotype has the lowest regardless of water regime (Fig. 2A).

Highly significant differences between the three water regimes in Tissemsilt ( $\mathrm{ddl}=2$; value $\mathrm{F}=9.38 ; \mathrm{P}=0.0035)$ and Zeralda ecotypes ( $\mathrm{ddl}=2 ;$ Value $\mathrm{F}=20.25$; $\mathrm{P}<0.0001$ ) with $\mathrm{R} 2=60.99 \%$, and no significant difference between the three water regimes of Ain Sefra ecotype were observed for RWC.

In control plants, the highest values of stomata conductance were noted in Ain Sefra ecotype with $11.16 \pm 1.12 \mathrm{mmol} \mathrm{H}_{2} \mathrm{O} / \mathrm{m}^{2} / \mathrm{s}$. Moderate and severe water stress cause a slight decrease in stomata conductance in Zeralda and Tissemsilt ecotypes. The most significant decrease was, however, recorded in Ain Sefra ecotype (Fig. 2B). We have noted that drought stress (moderate and severe stress) significantly reduced $(\mathrm{P}<0.001)$ 
stomata conductance of Ain Sefra ecotype ( $\mathrm{ddl}=2 ; \mathrm{F}=76.74 ; \mathrm{P}<0.0001)$. There is no significant variation in stomatal conductance in moderate and severe stress of Zeralda and Tissemsilt ecotypes.
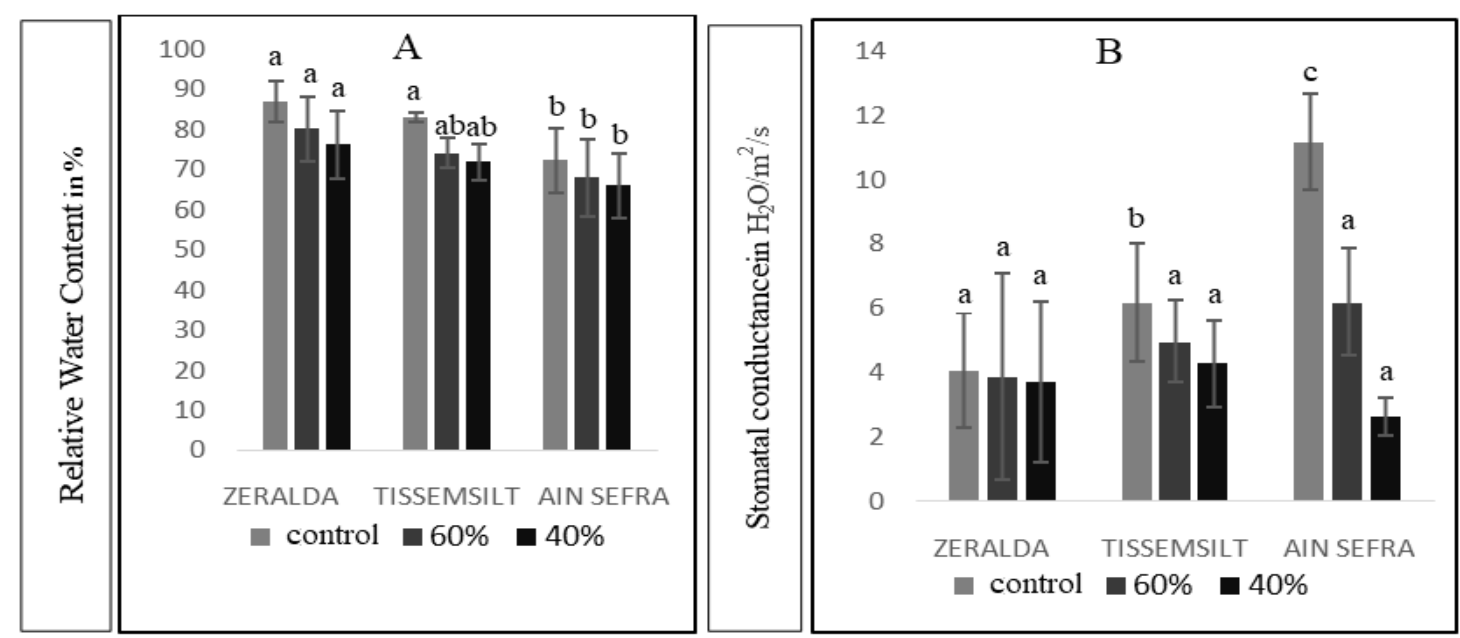

Figure 2. Effect of drought stress on leaf water content (A) and stomatal conductance (B) of three Ceratonia siliqua L. ecotypes. Eighteen-month-old young plants were exposed to three water regimes (control, 60 and $40 \%$ of field capacity $(F C)$ ) during 17 days. Mean $\pm S E(n=3)$ with distinct letters are significantly different at 5\% (Waller-Duncan test)

The statistical analysis shows that RWC and CS are strongly influenced by ecotype and water regimes $(\mathrm{p}<0.05)$. The water regime $(\mathrm{WR})$ has a significant effect on the expression of RWC ( $p<0.0001)$ and a significant variation $(\mathrm{p}<0.05)$ on CS. The interaction of the two factors (type of ecotype and water regime) also exerts significant variations on RWC and CS ( $\mathrm{p}<0.05$ ). Therefore, the ecotypes tested reaction distinctly with respect to the intensity of drought stress.

This study shows also that RWC is the first parameter affected by the progression of water stress severity of Zeralda and Tissemsilt ecotypes $(\mathrm{P}<0.001)$. Under drought stress, especially in severe water stress ( $40 \%$ of field capacity), we noticed a significant decrease in RWC compared to the control $(\mathrm{P}<0.001)$. However, we did not observe a significant difference in the different water regimes of Ain Sefra ecotype (Table 2).

Table 2. Statistical analysis of the variance of water regime (WR), ecotype (ECO) and $E C O \times$ WR interactions in Ceratonia siliqua $L$.

\begin{tabular}{c|c|c|c|c|c|c}
\hline & \multicolumn{2}{|c|}{ ECO } & \multicolumn{2}{c|}{ WR } & \multicolumn{2}{c}{ ECO $\times$ WR } \\
\hline RWC & 29.88 & $<.0001$ & 18.82 & $<.0001$ & 2.72 & 0.0319 \\
\hline CS & 16.8 & $<.0001$ & 7.12 & 0.0011 & 5.48 & 0.0004 \\
\hline
\end{tabular}

\section{Biochemical parameters}

Stressed plants showed significantly higher concentrations of soluble sugars (Fig. 3A) and proline than control plants (Fig. 3B). An increase in the level of proline and soluble sugar, which is a function of the severity of stress in the studied ecotypes, is 
observed. In severe drought stress, the highest concentrations of proline and soluble sugars were found in the Ain Sefra ecotype (Fig. 3).
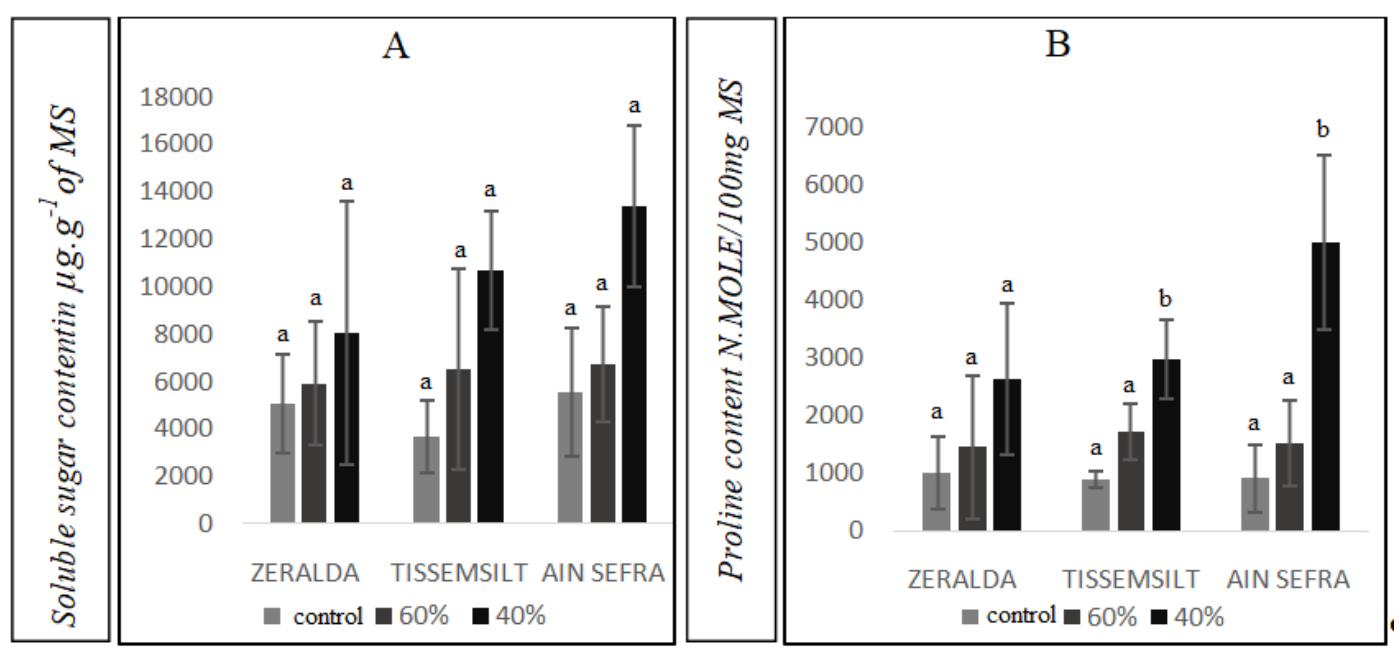

Figure 3. Effect of drought stress on prolin content and soluble sugar of three Ceratonia siliqua L. ecotypes. Eighteen-month-old young plants were exposed to three water regimes (control, 60 and $40 \%$ of field capacity $(F C))$. Mean $\pm S E(n=3)$ with distinct letters are significantly different at 5\% (Waller-Duncan test)

A very high significant difference was detected in the concentration of the proline between the different water regime of Zeralda, Tissemsilt and Ain Sefra (Table 3).

Water Regime has a tremendous effect on proline and soluble sugar accumulation $(\mathrm{p}<.0001)$. The interaction of the two factors exerts also significant variations $(\mathrm{p}<0.05)$ while the ecotype factor has no significant effect (Table 4).

Table 3. Analysis of variance of the proline and soluble sugars of the plants of Ceratonia siliqua Lunder three water regimes (control, 60 and $40 \%$ of field capacity $(F C)$ )

\begin{tabular}{c|c|c|c|c|c|c}
\hline \multirow{2}{*}{} & \multicolumn{2}{|c|}{ Zeralda } & \multicolumn{2}{c|}{ Tissemsilt } & \multicolumn{2}{c}{ Ain Sefra } \\
\cline { 2 - 7 } & F & P & F & P & F & P \\
\hline Proline & 22.33 & $<0.0001$ & 16.76 & 0.0003 & 45.34 & $<0.0001$ \\
Soluble sugars & 6.33 & 0.0025 & 5.33 & 0.0221 & 17.12 & $<0.0001$ \\
\hline
\end{tabular}

The relationship between the accumulation of proline and the water regime was studied using the regression procedure of SAS 9. We have found a strong positive correlation between the accumulation of proline and the water regime ( $\mathrm{ddl}=1$; value of the test $\mathrm{t}=8.87 ; \mathrm{p}<0.0001$ ).

Table 4. Statistical analysis of the variance of water regime (WR), ecotype (ECO) and $E C O \times$ WR interactions in Ceratonia siliqua $L$.

\begin{tabular}{c|c|c|c|c|c|c}
\hline \multirow{2}{*}{} & \multicolumn{2}{|c|}{ ECO } & \multicolumn{2}{c|}{ WR } & \multicolumn{2}{c}{ ECO(WR) } \\
\cline { 2 - 7 } & F & Pr $>$ F & F & Pr $>$ F & F & Pr $>$ F \\
\hline Proline & 1.06 & 0.3502 & 49.74 & $<.0001$ & 6.26 & 0.0001 \\
Soluble sugar & 1.77 & 0.1737 & 15.86 & $<.0001$ & 2.7 & 0.0329 \\
\hline
\end{tabular}


Our results show a notable difference in soluble sugars of Ain Sefra's ecotype. In contrast, there has been a significant difference between Zeralda and Tissemsilt (Table 3).

In control plants, the highest values of total chlorophyll were observed in Zeralda's ecotype with $4.70 \pm 2.23 \mu \mathrm{g} . \mathrm{mL}^{-1}$. For the three ecotypes, total chlorophyll contents are lower in stressed plants compared to control plants (Fig. 4A).
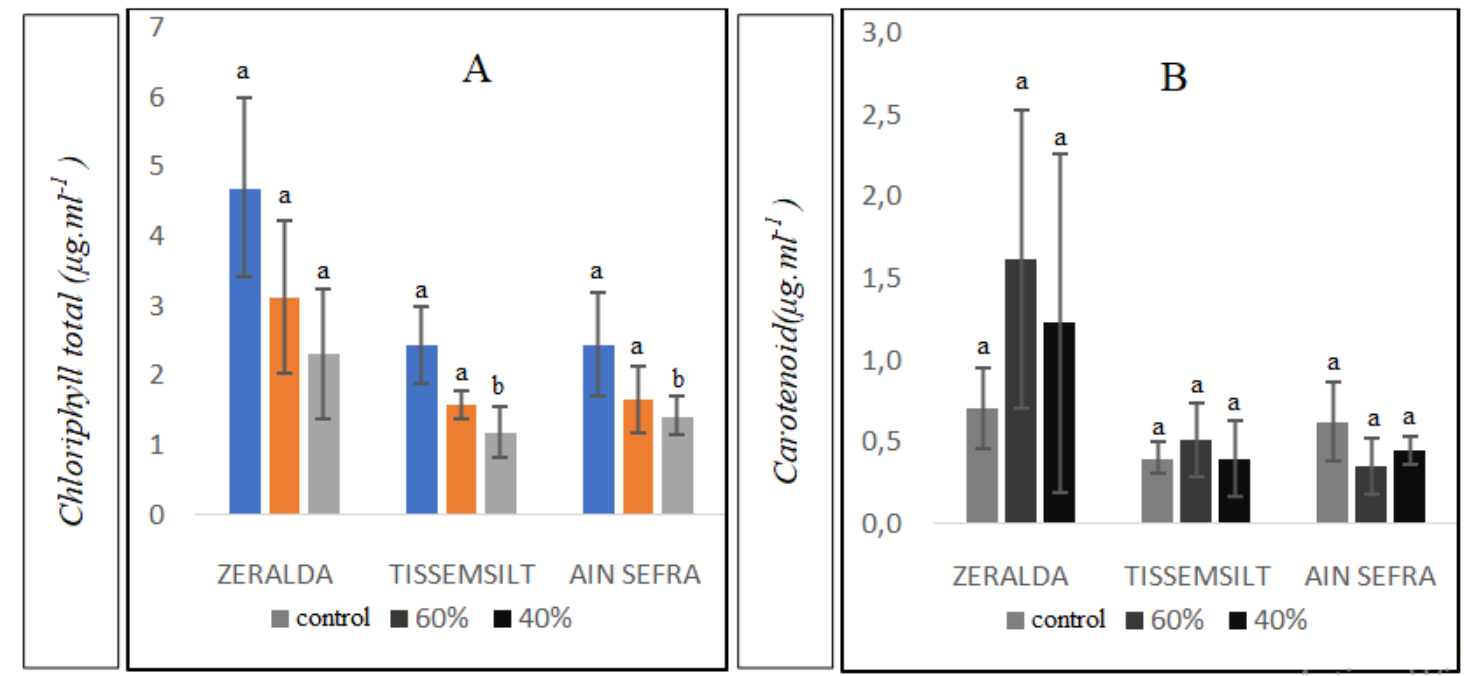

Figure 4. Effect of drought stress on chl T and carotenoids of three Ceratonia siliqua L. ecotypes. Eighteen-month-old young plants were exposed to three water regimes (control, 60 and $40 \%$ of field capacity). Mean $\pm S E(n=3)$ with distinct letters are significantly different at $5 \%$ (Waller-Duncan test)

Significant differences in the total chlorophyll content between the three water regimes $(\mathrm{F}=4.60, \mathrm{P}=0.0119),(\mathrm{F}=12.64, \mathrm{P}=0.0011)$ and $(\mathrm{F}=8.71, \mathrm{P}=0.0012)$ are recorded in Zeralda, Tissemsilt and Ain Sefra ecotypes respectively (Table 5).

Table5. Statistical analysis of the variance of water regime (WR), ecotype (ECO) and ECOxWR interactions in Ceratonia siliqua $L$.

\begin{tabular}{c|c|c|c|c|c|c}
\hline \multirow{2}{*}{} & \multicolumn{2}{|c|}{ Zeralda } & \multicolumn{2}{c|}{ Tissemsilt } & \multicolumn{2}{c}{ Ain Sefra } \\
\cline { 2 - 7 } & F & Pr $>$ F & F & Pr $>$ F & F & Pr $>$ F \\
\hline Chlorophyll & 4.60 & 0.0119 & 12.64 & 0.0011 & 8.71 & 0.0012 \\
Caroténoid & 4.62 & 0.0118 & 0.51 & 0.6138 & 6.08 & 0.0066 \\
Raportchl a/b & 3.90 & 0.0230 & 1.11 & 0.3637 & 13.21 & 0.0001 \\
\hline
\end{tabular}

Water regimes altered the content of carotenoids among the ecotypes of Ain Sefra $(\mathrm{F}=6.08 ; \mathrm{P}=0.0066)$ and Zeralda $(\mathrm{F}=4.62 ; \mathrm{P}=0.0118)$, but not for the ecotype of Tissemsilt. The greatest value of the carotenoid has been recorded in the ecotype of Zeralda under moderate stress with $1.65 \pm 0.92 \mu \mathrm{g} \cdot \mathrm{ml}^{-1}$ (Fig. 4B).

The highest $\mathrm{Chl}$ a/b ratio for the control plants was noted in Ain Sefra's ecotype. It significantly decreased in stressed plants of Ain Sefra $(\mathrm{F}=13.21, \mathrm{P}=0.0001)$ and 
Zeralda $(\mathrm{F}=3.90, \mathrm{P}=0.023$ ) ecotypes (Table 6). Conversely, WR has no significant effect on the $\mathrm{Chl} \mathrm{a} / \mathrm{b}$ ratio Tissemsilt's ecotype $(\mathrm{p}<.0001)($ Table 5$)$.

Table 6. Effect of drought stress on ratio Chlorophyll a/b of three Ceratonia siliqua L. ecotypes. Eighteen-month-old young plants were exposed to three water regimes $(100,60$ and $40 \%$ of FC) during 17 days. Mean $\pm S E(n=3)$

\begin{tabular}{c|c|c|c}
\hline \multirow{2}{*}{} & \multicolumn{3}{|c}{ Chlorophyll a/b } \\
\cline { 2 - 4 } & $\mathbf{1 0 0 \%}$ & $\mathbf{6 0 \%}$ & $\mathbf{4 0 \%}$ \\
\cline { 2 - 4 } & $1.40 \pm 0.78$ & $1.79 \pm 0.93$ & $2.02 \pm 1.42$ \\
Zeralda & $1.06 \pm 0.36$ & $1.36 \pm 0.42$ & $1.66 \pm 0.33$ \\
Tissemsilt & $2.20 \pm 1.06$ & $0.78 \pm 0.43$ & $0.72 \pm 0.43$ \\
Ain Sefra &
\end{tabular}

\section{Canonical analysis}

The analysis of principal components (APC) of osmolytes shows two separate groups (Fig. 5; Tables 7 and 8). The first group includes the stands in the region of Zeralda. In the second group, there are still two sub-groups; one constituted of the whole samples of Tissemsilt and the other formed by the samples of Ain Sefra.

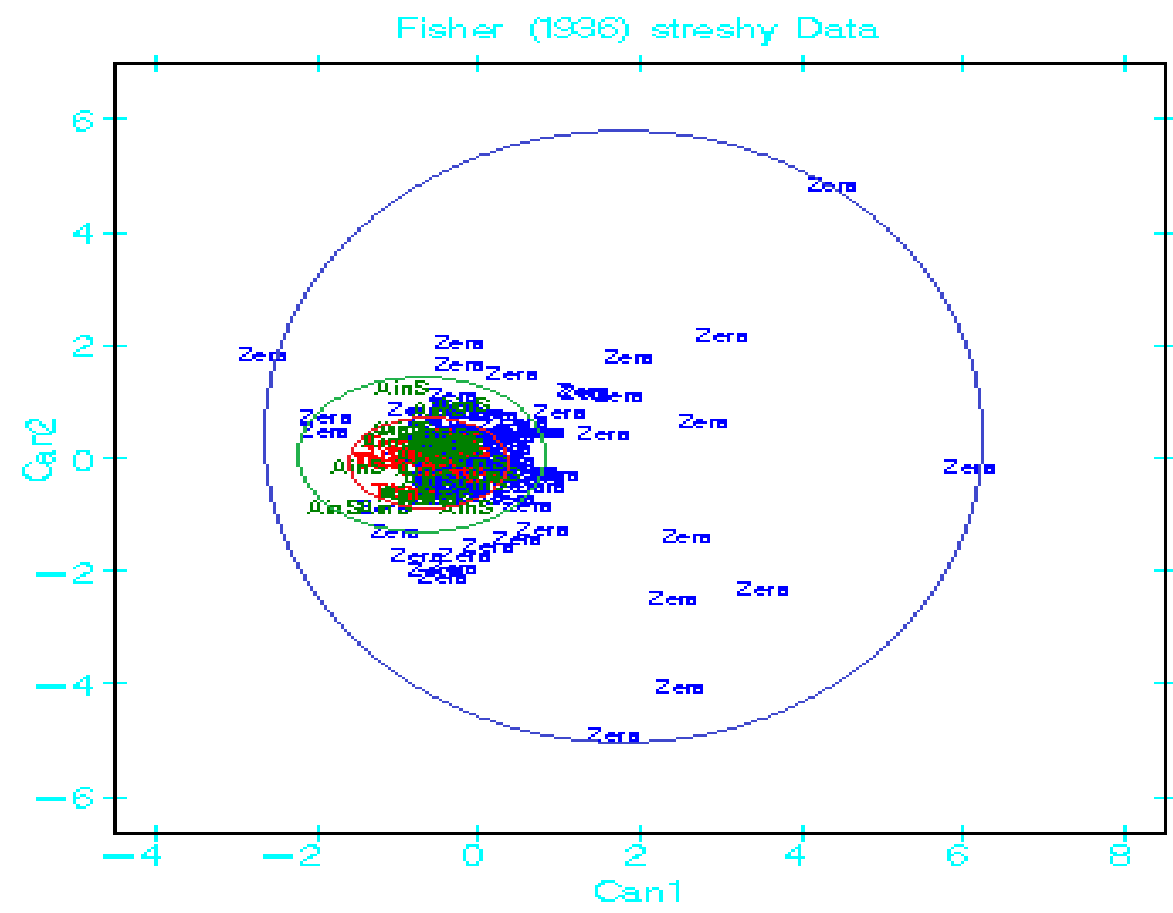

Figure 5. Projection of points means of the regions studied on the first plan factorial of a principal component analysis

Table 7 shows the point's means of the regions on the canonical variables. Group one is represented by Zeralda ecotype (means points $(0.22 /-0.0007)$ ) and the group two is represented by ecotypes of Tissemsilt (means points $(-0.63 / 0.061)$ ) and Ain Sefra (means points $(-0.55 / 0.033)$ ) ecotypes. 
Table 7. Medium of classes on the canonical variables

\begin{tabular}{c|c|c}
\hline \multicolumn{3}{c}{ Class meanings on canonical variables } \\
\hline Ecotype & Can1 & Can2 \\
\hline Ain Sefra & -0.5528 & 0.0338 \\
Tissemsilt & -0.6304 & -0.0616 \\
Zeralda & 0.2225 & -0.0007 \\
\hline
\end{tabular}

This interpretation is performed according to the plan 1-2 because it provides the maximum of information with $100 \%$ contribution to the total variation $(99.56 \%$ of contribution for the axis 1 and $0.44 \%$ for the axis 2 ).

The values of squared distance, estimated between ecotypes studied two by two, do not exceed 3.002, indicating an overlap between the ecotypes (Table 8).

The first group includes the ecotypes of the locality of Zeralda. The second group brings together the stands of the locality of Tissemsilt. Finally, the third group is represented by the stands from the locality of Ain Sefra.

According to Table 8, squared distance between ecotype is less than 50 (maximum value 35 between Zeralda and Ain Sefra ecotype), which shows an overlap between the three studied ecotypes.

Table 8. Distance square, value of $F$ for the distance square and value of the probability of square distance between the different ecotypes

\begin{tabular}{|c|c|c|c|}
\hline \multicolumn{4}{|c|}{ Squared distance to ecotype } \\
\hline & Ain Sefra & Tissemsilt & Zeralda \\
\hline Ain Sefra & 0 & 0.01513 & 0.60256 \\
\hline Tissemsilt & 0.01513 & 0 & 0.73136 \\
\hline zeralda & 0.60256 & 0.73136 & 0 \\
\hline \multicolumn{4}{|c|}{ F statistics } \\
\hline & Ain Sefra & Tissemsilt & Zeralda \\
\hline Ain Sefra & 0 & 0.02950 & 2.80515 \\
\hline Tissemsilt & 0.02950 & 0 & 1.89583 \\
\hline zeralda & 2.80515 & 1.89583 & 0 \\
\hline \multicolumn{4}{|c|}{ Prob> } \\
\hline & Ain Sefra & Tissemsilt & Zeralda \\
\hline Ain Sefra & 1.0000 & 0.9996 & 0.0187 \\
\hline Tissemsilt & 0.9996 & 1.0000 & 0.0981 \\
\hline zeralda & 0.0187 & 0.0981 & 1.0000 \\
\hline
\end{tabular}

With respect to the parameters of RWC and CS, the graphical interpretation of the APC results is performed mainly in function of the plan 1-2 because it provides the maximum information with $100 \%$ contribution to the total variation $(99.41 \%$ contribution of the axis 1 and $0.59 \%$ for axis 2) (Fig. 5)

Figure 6 shows the projection of the point's means of colonies on the first plan of a CPA. It is to show a clear differentiation in 3 distinct groups (Fig. 6; Table 9). 


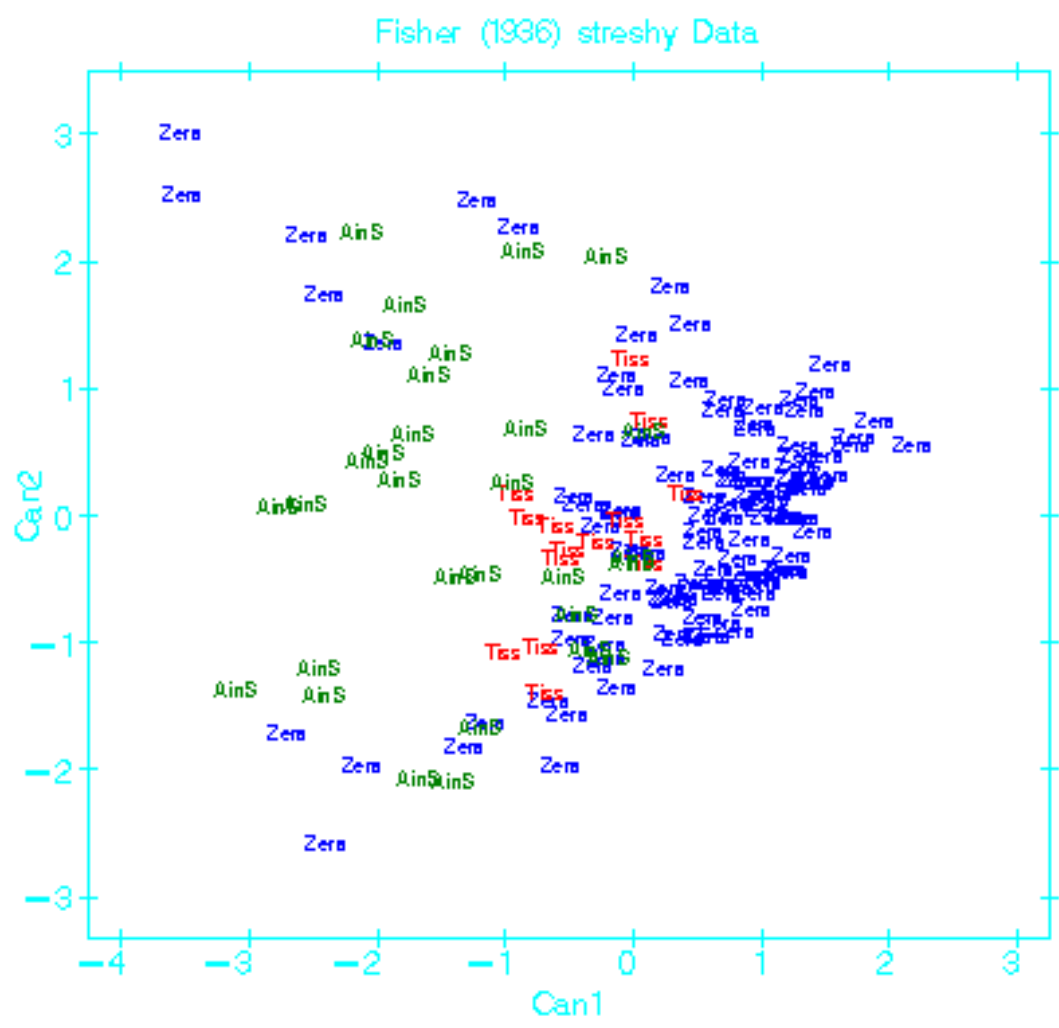

Figure 6. Projection of the points means the regions studied on the first plan factorial of a principal component analysis

Table 9. Distance square, value of $F$ for the distance square and value of the probability of square distance between the different ecotypes

\begin{tabular}{|c|c|c|c|}
\hline \multicolumn{4}{|c|}{ Squared distance to ecotype } \\
\hline & Ain Sefra & Tissemsilt & Zeralda \\
\hline Ain Sefra & 0 & 1.02765 & 3.00215 \\
\hline Tissemsilt & 1.02765 & 0 & 0.57412 \\
\hline Zeralda & 3.00215 & 0.57412 & 0 \\
\hline \multicolumn{4}{|c|}{ F statistics } \\
\hline & Ain Sefra & Tissemsilt & Zeralda \\
\hline Ain Sefra & 0 & 5.10594 & 35.61659 \\
\hline Tissemsilt & 5.10594 & 0 & 3.79260 \\
\hline Zeralda & 35.61659 & 3.79260 & 0 \\
\hline \multicolumn{4}{|c|}{ prob> } \\
\hline & Ain Sefra & Tissemsilt & Zeralda \\
\hline Ain Sefra & 1.0000 & 0.0071 & $<, 0001$ \\
\hline Tissemsilt & 0.0071 & 1.0000 & 0.0246 \\
\hline Zeralda & $<, 0001$ & 0.0246 & 1.0000 \\
\hline
\end{tabular}

Table 10 shows the points means of the regions on the canonical variables Zeralda (0.38/0.011), Tissemsilt (-0.348/-0.160) and Ain Sefra (-1.343/0.034). 
Table 10. Medium of classes on the canonical variables

\begin{tabular}{c|c|c}
\hline \multicolumn{3}{c}{ Class meanings on canonical variables } \\
\hline Ecotype & Can1 & Can2 \\
\hline Ain Sefra & -1.3433 & 0.0342 \\
Tissemsilt & -0.3486 & -0.1608 \\
Zeralda & 0.3891 & 0.0118 \\
\hline
\end{tabular}

According to the canonical analysis, the ecotypes Ain Sefra and Zeralda are well differentiated for all parameters studied. But Tissemsilt is getting closer to Zeralda for proline and soluble sugar parameters and form a different group for rwc and cs parameters.

\section{Discussion}

Drought stress is the key factor influencing plant growth and development in arid and semi-arid areas (Passioura, 2007). The assessment of the impact of the drought on the behaviour of plants includes mainly the estimate of their level of hydration. Thus, the RWC is a physiological indicator that is often used to assess the water status of the plant (Teulat et al., 1997). It has also been proposed as an important physiological indicator of the state of hydration in the function of the water regime (Lawlorand Cornic, 2002; Mefti et al., 2002).

Our results show that the water deficit is accompanied with a net decrease in the relative water content and stomata conductance in relationship with the intensity of water stress. The decrease of relative water content and stomata conductance documented in our study was in accordance with previous data (Maamar et al., 2015; Lassouane et al., 2013; Chakhchar et al., 2015b). The decrease in RWC is greater in Ain Sefra's ecotype. These two parameters are considered as the main responses against stress which is expressed by the stomata closure to minimize the water loss (Pita et al., 2005). This agrees with the results of some studies in a wide variety of plants (Nayyar and Gupta, 2006; Shultz, 2003). Under drought stress, the stomata closure with the decrease of their conductance constitutes one factor of plants drought tolerance (Yamaguchi-Shinozaki and Shinozaki, 2006).

A significant relationship between RWC increase and low stomata conductance was observed among the three contrasted ecotypes with a very significant stomata closure, which plays a very effective role in the prevention of the water loss (Medrano et al., 2002; Flexas et al., 2004).

The water deficit tolerance of plants is realized also through the maintenance of a low water potential (Blum, 2005). This strategy is mainly based on the osmotic adjustment, provided by the accumulation of a large diversity of osmolytes (Jalil et al., 2007; Sankar et al., 2007). Proline was considered as an osmolyte compatible which protects subcellular structures and macromolecule under osmotic stress (Kavi-Kishor et al., 2005). It may, also, increase the activity of many enzymes and stabilize protein integrity (Szabo and Savoure, 2010; Lipiec et al., 2013). In another context, the accumulation of the proline plays a very important role in the absorption of water (Ashraf and Foolad, 2007; Miller et al., 2010) to ensure osmotic adjustment which is the main physiological characteristics of tolerance (Manivannan et al., 2008). 
Our study results show a significant accumulation of proline and soluble sugars at the three studied ecotypes, with different degrees under water deficit. Hence, the ecotype Ain Sefra has the highest accumulation of proline and soluble sugars. We suggest that this ecotype is associated with a high tolerance to drought compared to other ecotypes. A significant increase of proline content in drought stress has been recorded in several species such as Olive (Sofo et al., 2005; Boughallleb and Mhamdi, 2011), poplar (Yin et al., 2005), and rice (Mostajeran and Rahimi-Eichi, 2009). The accumulation of proline in dehydrated seedlings is the consequence of the activation of the proline biosynthesis and inhibition of its degradation (Nakashima et al., 1998). Furthermore, the accumulation of soluble sugars allows to protect the membranes and proteins in cells exposed to a water deficit and reduce the aggregation of denatured proteins (Ashraf and Harris, 2003). The involvement of these two osmoticumin the osmotic adjustment allows the maintenance of cell turgorat the highest level possible for low water potentials, thus maintaining the photosynthetic activity, membranes structure and growth (Lawlor and Cornic, 2002; Farooq et al., 2008).

The chlorophyll pigment content in the leaves is a good indicator to the detection of stress and the tolerance of the plants subjected to stress (Chakhchar et al., 2015a). Our results have shown that water deficit induced a significant decrease in the concentration of chlorophyll and carotenoids in the leaves of Ceratonia siliqua L., which is in agreement with the results of Smirnoff (1993). The decrease of chlorophylls documented in our study was in accordance with previous data (Cui et al., 2004; Lei et al., 2006). This diminution may be due to a low chlorophyll biosynthesis or their degradation (Bacelar et al., 2006). The stress response varies considerably between species, genotypes and even between the parts of the same plants (Kozlowski et Pallardy, 2002). There were clear intraspecific differences in stomatal sensitivity, proline content, RWC, soluble sugars and chlorophylls, suggesting different adaptations to drought related to the ecotype effect and significant genetic variability in carob populations in Algeria. The same results were obtained by (Chakhchar, 2015b; Maamar, 2015).

According to the APC (analysis of principal component), all three ecotypes separated into three different groups. Thus, we find that the ecotype of the arid zone (AinSefra) was the most tolerant ecotype; it can be used in future reforestation programs in the semi-arid area of Algeria.

\section{Conclusions}

An integrated study combining of physiological and biochemical analysis has been adopted to study the reactions and behavior of Ceratonia siliqua toward the water stress. Significant differences between ecotypes were recorded in leaves water status, the content of photosynthetic pigments, and the accumulation of osmoregulators.

This study shows that the water deficit is accompanied with a net decrease in the relative water content, stomata conductance, and a significant increase in the accumulation of proline and soluble sugars of the three studied ecotypes.

The canonical analysis classified of Ain Sefra ecotype as the most tolerant one from the arid zone and suggested the following order of the ecotypes with respect to the drought tolerance: the Ain Sefra (arid zone) - the Tissemsilt (semi-arid zone) - the Zeralda (sub-humid zone). 
According to the analysis of principal components, the three ecotypes were distinguished on the basis of the RWC, CS, proline accumulation and soluble sugar. Ain Sefra ecotype is more likely to be the most droughts tolerant and very promising to the regeneration of carob tree cultivation in Algeria in arid and semi-arid areas.

\section{REFERENCES}

[1] Aafi, A. (1996): Le caroubier: Caractères botaniques et écologiques, groupements végétaux, techniques d'élevage en pépinière, traitement et soins culturaux, utilisation et production. - Centre national de la recherche forestière, Maroc, pp. 1-7.

[2] Ait Chitt, M., Belmir, H., Lazrak, A. (2007): Production de plants sélectionnés et greffés de caroubier. - Transfert de technologie en agriculture, Maroc. 153: 1-4.

[3] Albouchi, A., Bejaoui, Z., Hedi el Aouni, M. (2003): Influence d'un stress hydrique modéré ou sévère sur la croissance de jeunes plants de Casuarina glaucaSieb. - Edit. Science et changements planétaires, Sécheresse 14(3): 137-142.

[4] ANAT (Agence Nationale de l'Aménagement du Territoire) (2004): Carte bioclimatique de l'Algérie. - ANAT, Kouba, Algeria.

[5] Ashraf, M., Foolad, M. R. (2007): Roles of glycine betaine and proline in improving plant abiotic stress resistance. - Environmental and Experimental Botany 59: 206-216.

[6] Ashraf, M., Harris, P. J. C. (2003): Potential biochemical indicators of salinity tolerance in plants. - Plant Science 166: 3-16.

[7] Bacelar, E. A., Santos, D. L., Moutinho-Pereira, J., Gonçalves, B. C., Ferreira, H. F., Correia, C. M. (2006): Immediate responses and adaptative strategies of three olive cultivars under contrasting water availability regimes: Changes on structure and chemical composition of foliage and oxidative damage. - Plant Sci. 170: 596-605.

[8] Batlle, I., Tous., J. (1997): Carob Tree. Ceratonia siliqua L. Promoting the Conservation and Use of Under Utilized and Neglected Crops. - 17. Institute of Plant Genetic and Crops Plant Research. Gatersleben/International Plant Resources Institute, Rome, Italy.

[9] Benbelkacem, A., Kellou, K. (2000): Evaluation du progrès génétique chez quelques variétés de blé dur (TriticumdurumDesf) cultivées en Algérie. - Option méditerranéenne. Série A. Séminaire méditerranéen $n^{\circ} 40$.

[10] Blum, A. (2005): Drought resistance, water-use efficiency, and yield potential—are they compatible, dissonant, or mutually exclusive? - Aust J Agric Res 56: 1159-1168.

[11] Boughallleb, F., Mhamdi, M. (2011): Possible involvement of proline and the antioxidant defense systems in the drought tolerance of three olive cultivars grown under increasing ater deficit regimes. - Agric. J. 6: 378-391.

[12] Chakhchar, A., Lamaoui, M., Ferradous, A., Wahbi, S., El Mousadik, A., IbnsoudaKoraichi, S., Filali-Maltouf, A., El Modafar, C. (2015a): Differential drought tolerance of four contrasting Arganiaspinosa ecotypes assessed by enzymatic and non-enzymatic antioxidant. - Int J Recent Sci Res. 6: 3002-3009.

[13] Chakhchar, A., Lamaoui, M., Wahbi, S., Ferradous, A., El Mousadik, A., IbnsoudaKoraichi, S., Filali-Maltouf, A., El Modafar, C. (2015b): Leaf water status, osmoregulation and secondary metabolism as a model for depicting drought tolerance in Argania spinosa. - Acta Physiol Plant. 37: 1-16.

[14] Chaves, M. M., Maroco, J. P., Pereira, J. (2003): Understanding plantresponses to drought-from genes to the whole plant. - Funct Plant Biol 30: 239-264.

[15] Clarke, J. M., McCaig, T. N. (1982): Evaluation of techniques for screening for drought resistance in wheat. - Crop Sci. 22: 503-506.

[16] Cui, Y. Y., Pandey, D. M., Hahn, E. J. et al. (2004): Effect of drought on physiological aspects of Crassulacean acid metabolism in Doritaenopsis. - Plant Sci 167: 1219-26. 
[17] Farooq, M., Basra, S. M. A., Wahid, A., Cheema, Z. A., Cheema, M. A., Khaliq, A. (2008): Physiological role of exogenously applied glycinebetaine in improving drought tolerance of fine grain aromatic rice (Oryza sativa L.). - J Agron Crop Sci 194: 325-333.

[18] Flexas, J., Bota, J., Loreto, F., Comic, G., Sharkey, T. D. (2004): Diffusive and metabolic limitations to photosynthesis under drought and salinity in C3 plants. - Plant Biol 6: 269279.

[19] Gales, K. (1979): Effect of water supply on partitioning of dry matter between roots and shoots in Lolium perenne. - App Ecol 16: 863-877.

[20] Gharnit, N., EtMtili, N., Ennabili, A. T., Ennabili, A. (2001): Social characterization and exploitation of carob tree (Ceratonia siliqua L.) from Mokrisset and Bab Taza (NW of Morocco). - Sci. Lett. 3(2).

[21] Jalil, C. A., Gopi, R., Sankar, B., Manivannan, P., Kishorkumar, A., Sridharan, R. (2007): Studies on germination, seedling vigor, lipid peroxidation and proline metabolism in Catharanthusroseus seedlings under salt stress. - South Afr J Bot 73: 190-195.

[22] Kavi-Kishor, P. B., Sangam, S., Amrutha, R. N., Sri-Laxmi, P., Naidu, K. R., Rao, K. R. S. S., Rao, S., Reddy, K. J., Theriappan, P., Sreenivasulu, N. (2005): Regulation of proline biosynthesis, degradation, uptake and transport in higher plants: Its implications in plant growth and abiotic stress tolerance. - Current Science 88: 424-438.

[23] Konate, I. (2007): Diversité Phénotypique et Moléculaire du Caroubier (Ceratonia siliqua L.) et des Bactéries Endophytes qui lui sont Associées. - Université Mohammed V Agdal Faculté des Sciences.

[24] Ladiges, P. (1975): some aspects of tissue water relations in three populations of eucalyptus viminalisLABILL. - New Phytol.75: 53-62.

[25] Lambers, H., Chapin, F. S., Pons, T. L. (2008): Plant Physiological Ecology. 2nd Edn. Springer, New York.

[26] Lassouane, N., Aïd, F., Lutts, S. (2013): Water stress impact on young seedling growth of Acacia arabica. - Acta Physiol Plant 35: 2157-2169.

[27] Lawlor, D. W., Cornic, G. (2002): photosynthetic carbon assimilation and associated metabolism in relation to water deficits in higher plants. - Plant Cell \& Environment 25: 275-294.

[28] Le Houérou, H. N. (1985): La régénération des steppes algériennes. - Rapport de mission de consultation et d'évaluation. Ministère de l'agriculture, Alger, ronéotypé.

[29] Lei, Y., Yin, C., Li, C. (2006): Differences in some morphological, physiological, and biochemical responses to drought stress in two contrasting populations of Populus przewalskii. - Physiol Plant 127: 182-91.

[30] Letreuch Belarouci, N. (1991): Les reboisements en Algérie et leur perspective d'avenir. Volume I. - OPU, Alger.

[31] Li, Y. P., Ye, W., Wang, M., Yan, X. D. (2009): Climate change and drought: a risk assessment of cropyield impacts. - Climate Res 39: 31-46.

[32] Lichtenthaler, H. K. (1987): Chlorophylls and carotenoids: pigments of photosynthetic biomembranes. - Methods Enzymol. 148: 350-382.

[33] Lipiec, J., Doussan, C., Nosalewicz, A., Kondracka, K. (2013): Effect of drought and heat stresses on plant growth and yield: A review. - Int. Agrophys. 27: 463-477.

[34] Maamar, B., Maatoug, M., Iriti, M., Dellal, A. (2015): Physiological effects of ozone exposure on De Colgar and Rechaiga II tomato (Solanum lycopersicum L.) cultivars. Environ Sci Pollut Res 22: 12124-12132.

[35] Magné, C., Larher, F. (1992): High sugar content of extracts interferes with colorimetric determination of amino acids and free proline. - Analytical Biochemistry 200: 115-118.

[36] Mahdad, M. Y., Gaouar, S. B. S. (2016): Le Caroubier (Ceratonia siliqua L.) dans le Nord-ouest de l'Algérie: Situation et perspectives d'amélioration. - Éditions universitaires européennes, France. 
[37] Manivannan, P., Jaleel, C. A., Somasundaram, R., Panneerselvam, R. (2008): Osmoregulation and antioxidant metabolism in drought stressed Helianthus annuusunder triadimefon drenching. - Comp. Rend. Biol. 331: 418-425.

[38] Medrano, H., Escalona, J. M., Bota, J., Gulías, J., Flexas, J. (2002): Regulation of photosynthesis of $\mathrm{C} 3$ plants in response to progressive drought: stomatal conductance as a reference parameter. - Ann Bot 89: 895-905.

[39] Mefti, M., Abdelguerfi, A., Chebouti, A. (2002): Etude de la tolérance à la sécheresse chez quelques espèces de Médicago truncatula (L.) Gaertn. - In: Delgado, I., Lloveras, J. (eds.) Quality in Lucerne and Medics for Animal Production. CIHEAM, Zaragoza. pp. 173-176.

[40] Miller, G., Suzuki, N., Ciftci-Yilmaz, S., Mittler, R. (2010): Reactive oxygen species homeostasis and signalling during drought and salinity stresses. - Plant Cell Environ. 33: 453-467.

[41] Mostajeran, A., Rahimi-Eichi, V. (2009): Effects of drought stress on growth and yield of rice (Oryza sativa L.) Cultivars and accumulation of proline and soluble sugars in sheath and blades of their different ages leaves. - American-Eurasian Journal of Agricultural and Environmental Science 5: 264-272.

[42] Nakashima, K., Satoh, R., Kiyosue, T., Yamaguchi-Shinozaki, K., Shinozaki, K. (1998): A gene encoding proline dehydrogenase is not only induced by proline and hypoosmolarity, but is also developmentally regulated in the reproductive organs of Arabidopsis. - Plant Physiology 118: 1233-1241.

[43] Nautiyal, C. S., Bhaduria, S., Kumar, P., Lal, H., Mondal, R., Verma, D. (2000): An efficient microbiological growth medium for screening phosphate solubilizing microorganisms. - FEMS Microbiol. Lett. 182: 291-296.

[44] Nayyar, H., Gupta, D. (2006): Differential sensitivity of C3 and C4 plants to water deficit stress: Association with oxidative stress and antioxidants. - Environmental and Experimental Botany 58: 106-113.

[45] Nogués, S., Baker, N. R. (2000): Effects of drought on photosynthesis in Mediterranean plants grown under enhanced UV-B radiation. - J Exp Bot 51: 1309-1317.

[46] Okcu, G., Kaya, M. D., Atak, M. (2005): Effects of salt and drought stresses on germination and seedling growth of pea (Pisum sativum L.). - Turk J Agric For 29: 237242.

[47] Passioura, J. B. (2007): The drought environment: physical, biological and agricultural perspectives. - J. Exp. Bot. 58: 113-117.

[48] Pita, P., Cañas, I., Soria, F. Ruiz, F., Toval, G. (2005): Use of physiological traits in tree breeding for improved yield in drought-prone environments. The case of Eucalyptus globulus. - Invest Agrar: Sist Recur For 14: 383-393.

[49] Rascio, A., Cedola, M., Sorrentino, G., Pastore, D., Wittmer, G. (1988): Pressure volume curves and drought resistance in two wheat genotypes. - Physiol. Plant 73: 122-127.

[50] Reddy, A. R., Chiatanya, K. V., Vivekanandan, M. (2004): Drought induced responses of photosynthesis and antioxidant metabolism in higher plants. - J. Plant Physiol. 161: 1189 1202.

[51] Rejeb, M. N. (1995): Le caroubier en Tunisie: Situations et perspectives d'amélioration. Dans: Quel avenir pour l'amélioration des plantes? - Edit. AUPELF-UREF, John LibbeyEurotext, Paris, pp. 79-85.

[52] Reva, O. N., Smirnov, V. V., Petterson, B., Priest, F. G. (2002): Bacillusendophyticus sp. nov. isolated from the inner tissues of cotton plants (Gossypium sp.). - Int. J. Syst. Evol. Microbiol. 52: 101-107.

[53] Rodziewicz, P., Swarcewicz, B., Chmielewska, K., Wojakowska, A., Stobiecki, M. (2014): Influence of abiotic stresses on plant proteome and metabolome changes. - Acta Physiol Plant 36: 1-19. 
[54] Sankar, B., Jaleel, C. A., Manivannan, P., Kishorekumar, A., Somasundram, R., Panneerselvam, R. (2007): Drought-induced biochemical modifications and proline metabolism in Abel moschus esculentus (L.) Moench. - Acta Bot Croat 66: 43-56.

[55] Schields, M., Burnett, W. (1960): Determination of protein bound and carbohydrate in serum by modified anthrone method. - Ann. Chem. 32: 885-886.

[56] Shultz, H. R. (2003): Differences in hydraulic architecture account for earisohydric and anisohydric behaviour of two field-grown Vitis vinifera L. cultivars during drought. Plant Cell and Environ. 26: 1393-1405.

[57] Smirnoff, N. (1993): The role of active oxygen in the response of plants to water deficit and desiccation. - New Phytol. 125: 27-58.

[58] Sofo, A., Dichio, B., Xiloyannis, C., Masia, A. (2005): Antioxidant defences in olive trees during drought stress: changes in activity of some antioxidant enzymes. Functional Plant Biology 32: 45-53.

[59] Szabo, L., Savoure, A. (2010): Proline: a multifunctional amino acid. - Trends Plant Sci. 15(2), 89-97.

[60] Taiz, L., Zeiger, E. (2010): Plant Physiology. 5th Edn. - Sinauer Associates Inc. Publishers, Massachusetts.

[61] Tardieu, F. (2005): Plant tolerance to water deficit: physical limits and possibilities for progress. - C. R. Geoscience 337: 57-67.

[62] Teulat, B., Monneveux, P., Wery, J., Borries, C., Sourys, I., Charrier, A., This, D. (1997): Relationships between relative water content and growth parameters under water stress in barley: a QTL study. - New Phytol. 137: 99-107.

[63] Troll, W., Lindesly, J. (1955): A photometric method for the determination of proline. Journal of Biological Chemistry 215: 655-660.

[64] Yamaguchi-Shinozaki, K., Shinozaki, K. (2006): Transcriptional regulatory networks in cellular responses and tolerance to dehydration and cold stresses. - Annu Rev Plant Biol 57: 781-803.

[65] Yin, C., Peng, Y., Zang, R., Zhu, Y., Li, C. (2005): Adaptive responses of Populus kangdingensis to drought stress. - Physiologia Plantarum 123: 445-451.

[66] Yoon, S. K., Park, E. J., Choi, Y. I., Bae, E. K., Kim, J. H., Park, S. Y., Kang, K. S., Lee, H. (2014): Response to drought and salt stress in leaves of poplar (Populus alba $\times$ Populus glandulosa): Expression profiling by oligonucleotide microarray analysis. Plant Physiol Biochem. 26: 158-168. 